\title{
Barley shoot biomass responds strongly to N:P stoichiometry and intraspecific competition, whereas roots only alter their foraging
}

\author{
Amit Kumar • Richard van Duijnen • Benjamin M. \\ Delory • Rüdiger Reichel • Nicolas Brüggemann • \\ Vicky M. Temperton
}

Received: 19 February 2020 / Accepted: 28 June 2020 / Published online: 11 July 2020

(C) The Author(s) 2020

\begin{abstract}
Aims Root system responses to the limitation of either nitrogen $(\mathrm{N})$ or phosphorus $(\mathrm{P})$ are well documented, but how the early root system responds to (co-) limitation of one $(\mathrm{N}$ or $\mathrm{P})$ or both in a stoichiometric framework is not well-known. In addition, how intraspecific competition alters plant responses to N:P stoichiometry is understudied. Therefore, we aimed to investigate the effects of N:P stoichiometry and competition on root system responses and overall plant performance.

Methods Plants (Hordeum vulgare L.) were grown in rhizoboxes for 24 days in the presence or absence of competition (three vs. one plant per rhizobox), and fertilized with different combinations of N:P (low N + low $\mathrm{P}$, low $\mathrm{N}+$ high $\mathrm{P}$, high $\mathrm{N}+$ low $\mathrm{P}$, and high $\mathrm{N}+$ high $\mathrm{P}$ ).
\end{abstract}

Responsible Editor: Boris Rewald.

Electronic supplementary material The online version of this article (https://doi.org/10.1007/s11104-020-04626-w) contains supplementary material, which is available to authorized users.

A. Kumar $(\bowtie) \cdot$ R. van Duijnen · B. M. Delory •

V. M. Temperton $(\bowtie)$

Ecosystem Functioning and Services, Institute of Ecology, Faculty of Sustainability, Leuphana University Lüneburg,

Universitätsallee 1, 21335 Lüneburg, Germany

e-mail: akumar4@gwdg.de

e-mail: kumar@leuphana.de

e-mail: Vicky.temperton@leuphana.de

R. Reichel $\cdot$ N. Brüggemann

Forschungszentrum Jülich GmbH, Institute of Bio- and

Geosciences, Agrosphere (IBG-3), 52425 Jülich, Germany
Results Shoot biomass was highest when both $\mathrm{N}$ and $\mathrm{P}$ were provided in high amounts. In competition, shoot biomass decreased on average by $22 \%$. Total root biomass (per plant) was not affected by $\mathrm{N}: \mathrm{P}$ stoichiometry and competition but differences were observed in specific root length and root biomass allocation across soil depths. Specific root length depended on the identity of limiting nutrient ( $\mathrm{N}$ or $\mathrm{P}$ ) and competition. Plants had higher proportion of root biomass in deeper soil layers under $\mathrm{N}$ limitation, while a greater proportion of root biomass was found at the top soil layers under $\mathrm{P}$ limitation.

Conclusions With low $\mathrm{N}$ and $\mathrm{P}$ availability during early growth, higher investments in root system development can significantly trade off with aboveground productivity, and strong intraspecific competition can further strengthen such effects.

Keywords Root system responses - Vertical root distribution $\cdot$ Specific root length $\cdot$ Nutrient stoichiometry $\cdot$ Intraspecific competition

\section{Introduction}

Nutrient foraging capacity of roots determines plant performance under both heterogeneous soil nutrient availability and belowground competition with neighbors (Stibbe and Märländer 2002; Soleymani et al. 2011; Bennett et al. 2016; Reiss and Drinkwater 2018). Given that nutrient foraging by roots is an active process (Zhang et al. 2019), it is very likely that plant 
biomass allocation and root system responses will be driven by the nutrient which is limiting plant growth the most (Poorter et al. 2012). It has previously been shown for many crops how eco-physiological (Gastal and Lemaire 2002), morphological (Fransen and Berendse 1998), architectural (Williamson et al. 2001; Postma and Lynch 2012; Lynch 2013), and anatomical (Wahl et al. 2001; Postma and Lynch 2011) root traits respond to nitrogen $(\mathrm{N})$ and phosphorus $(\mathrm{P})$ availability in soil. For instance, Wang et al. (2015) showed contrasting root morphological and physiological trait responses of canola, barley, and potato in relation to low $\mathrm{P}$ availability. In order to increase P uptake, canola exuded more citric acid and developed longer roots, barley increased exudation of malic acid and reduced its root surface area and total root length, whereas potato reduced the exudation of organic acids but increased the number of root tips. Overall, it is clear that root systems respond in a speciesspecific way to nutrient stimuli by modifying their size and architecture (Kembel et al. 2008; Wang et al. 2015; McNickle et al. 2016). Further, Kembel and Cahill (2005) showed for more than 100 plant species that such nutrient foraging responses can be taxonomically and phylogenetically conserved. Thus, it is important to understand how plants respond to the balance between the availability of two major growth-limiting macronutrients $(\mathrm{N}$ and $\mathrm{P}$ ) with consequences on cell metabolism and overall growth and development. Addition of either $\mathrm{N}$ or $\mathrm{P}$ to soil increases their uptake and consequently plant growth. This suggests widespread $\mathrm{N}$ and $\mathrm{P}$ colimitation (Elser et al. 2010; Čapek et al. 2018). Leaf $\mathrm{N}: \mathrm{P}$ stoichiometry has previously been studied to establish their relationship with plant growth (Cornelissen et al. 1997; He et al. 2008). For instance, for optimal plant physiology, the elemental $\mathrm{N}$ and $\mathrm{P}$ ratio in plant biomass should be relatively stable (Güsewell 2004). Nitrogen is an integral part of most of the enzymatic machinery, and higher $\mathrm{N}$ than $\mathrm{P}$ demand in cell metabolism indicates that $\mathrm{N}$ limitation can severely affect plant growth and consequently biomass production. However, to what extent stoichiometric N:P availability in soil affects root systems and overall plant growth, and how the observed effect depends on the presence of intraspecific competition has been rarely tested. It is not clear whether plants (especially roots) respond similarly to varying $\mathrm{N}$ and $\mathrm{P}$ availability and if such responses are affected by intraspecific competition. Hence, it becomes important to understand the root foraging responses to stoichiometric availability of both
$\mathrm{N}$ and $\mathrm{P}$ during early plant establishment in a factorial manner with altered N:P mass ratio of low/high $\mathrm{N}$ and $\mathrm{P}$. Differences in mobility between $\mathrm{N}$ and $\mathrm{P}$ affect their availability to plants, and root responses are likely to be specific to nutrient distribution in soil. For example, $\mathrm{P}$ (as orthophosphate) is highly immobile in the soil and accumulates in the topsoil strata via plant residue and fertilizer inputs. Therefore, wide dispersion of lateral roots, enhanced adventitious rooting, and shallower root growth angles are among the key root responses that are associated with enhanced topsoil foraging for P (Lynch and Brown 2001; Lynch 2011). In contrast, N (as nitrate) is relatively mobile in the soil compared to $\mathrm{P}$ and moves down the soil strata with irrigation and precipitation events. Fewer crown roots in maize, for example, can potentially improve $\mathrm{N}$ acquisition by exploring deep soil strata, a key root system response (Saengwilai et al. 2014; Guo and York 2019). Therefore, the coordinated uptake and utilization of both $\mathrm{N}$ and $\mathrm{P}$ are essential in relation to optimal plant growth. However, very little is known about how plants adjust their biomass allocation and root growth responses to soil N:P stoichiometry. It is further not clear how co-limitation of both $\mathrm{N}$ and $\mathrm{P}$ will direct the plant's response for their uptake (Venterink and Güsewell 2010; Hu and Chu 2019).

Root responses not only depend on soil nutrient availability but also on the presence of neighbors (whether of the same or different species) through root-root competition for available nutrients (Cahill et al. 2010; Faget et al. 2013; McNickle and Brown 2014, Weidlich et al. 2018). Nutrient requirements are important determinant of plant-plant competition. This is particularly true in mono-cropping systems where there is strong intraspecific competition for soil nutrients, mainly because neighbors share the same lifehistory strategies and have similar resource demands. Intense competition results in a direct negative effect on plant growth and ultimately on yield (Craine and Dybzinski 2013; Bennett et al. 2016). Bennett et al. (2016) have shown interactive effects of nutrients with or without inter- and intraspecific competition on plant biomass allocation and root system responses for grasses, legumes, and forbs. Further, Hecht et al. (2016) showed for barley that roots respond to greater intraspecific competition (via manipulating sowing density) by increasing root length density and specific root length through increased fine root production. Later, Hecht et al. (2019) showed that the greater root length density under intraspecific competition was attributed to 
greater main root numbers. Moreover, root responses to the intraspecific competition may also include root segregation and aggregation to maximize the acquisition of nutrients (Cahill et al. 2010; Weidlich et al. 2018; Zhang et al. 2019).

Regardless of understanding how the availability of either $\mathrm{N}$ or $\mathrm{P}$ interacts with belowground competition to affect plant growth (Thuynsma et al. 2016; Sun et al. 2016), it is still unclear how plants integrate the responses to differential nutrient availability and the presence or absence of intraspecific competition during early growth stages. Therefore, the aim of this study was twofold: (1) investigating how $\mathrm{N}: \mathrm{P}$ stoichiometry in the soil solution affects plant performance and root system responses of barley (Hordeum vulgare L.); and (2) determining if intraspecific competition interacts with $\mathrm{N}: \mathrm{P}$ stoichiometry in shaping plant performance.

We hypothesized that:

(1) From the nutrient stoichiometry perspective, $\mathrm{N}$ is more limiting than $\mathrm{P}$ for plant growth and low availability of $\mathrm{N}$ has stronger effects than that of $\mathrm{P}$ on plant performance (both below- and aboveground).

(2) The intraspecific competition will lead to strong nutrient depletion, resulting in overall biomass reduction per plant.

(3) Root distribution and foraging strategy will be affected by N:P stoichiometry, with plants rooting deeper when $\mathrm{N}$ is limiting and shallower when $\mathrm{P}$ is limiting, and the strength of the response will be modulated by intraspecific competition.

\section{Materials and methods}

Experimental setup

The experiment was conducted in the greenhouse of the Leuphana University Lüneburg (Lüneburg, Germany, $53^{\circ} 14^{\prime} 23.8^{\prime \prime} \mathrm{N} 10^{\circ} 24^{\prime} 45.5^{\prime \prime} \mathrm{E}$ ) from August 18th 2017 to September 11th 2017 for a total of 24 days. The average day/night temperature and relative humidity were $22.3 / 15.3{ }^{\circ} \mathrm{C}$ and $60 / 73 \%$, respectively. A homogenous soil mixture was prepared using sand, loess soil (nutrient-poor, collected from a lignite mine near Jackerath, Germany), and peat potting soil (Nullerde, Einheitserde Werkverband e.V., Germany) in 8:2:1 ratio, respectively. Rhizoboxes (Height: $58 \mathrm{~cm} \times$ Width: $26.6 \mathrm{~cm} \times$ Thickness: $2 \mathrm{~cm}$; volume: $3 \mathrm{~L}$ ) were filled with $\sim 5 \mathrm{~kg}$ of soil mixture. Pre-germinated (pre-germination time: $24 \mathrm{~h}$ on a wet tissue paper) barley (Hordeum vulgare L. cv. Barke, Saatzucht Breun, Germany) seedlings were transplanted in rhizoboxes as shown in Fig. 1. Each rhizobox received 1 seedling for absence and 3 seedlings ( $7.5 \mathrm{~cm}$ apart from each other) for the presence of intraspecific competition (hereafter competition). Rhizoboxes were placed in containers at a $45^{\circ}$ angle and each container contained five rhizoboxes. In each container, the front rhizobox was covered with a black plastic plate and the last rhizobox was covered with a white polystyrene plate to maintain similar light and temperature conditions, respectively. Rhizobox position was randomly changed every fourth day.

The experiment was designed using a full factorial design to test how $\mathrm{N}: \mathrm{P}$ stoichiometry (four levels: low $\mathrm{N}+$ low $\mathrm{P}(\mathrm{LN}-\mathrm{LP})$, low $\mathrm{N}+$ high $\mathrm{P}(\mathrm{LN}-\mathrm{HP})$, high $\mathrm{N}+$ low $\mathrm{P}$ (HN-LP), and high $\mathrm{N}+$ high $\mathrm{P}(\mathrm{HN}-\mathrm{HP})$ ) (based on pre-test showing that shoot growth was limited by $\mathrm{N}$ only above a 'threshold' of low $\mathrm{P}$ availability) and intraspecific competition (two levels: absence or presence of competitors) affect biomass production and allocation, soil exploration by roots, and N:P uptake of barley. In total, 8 treatment combinations were tested (4 levels of N:P stoichiometry $\times 2$ levels of intraspecific competition) and each treatment was replicated five times resulting in a total of 40 experimental units (rhizoboxes). The mass ratio of 4 levels of N:P stoichiometry were 5.81 (for LN-LP), 1.45 (LN-HP), 22.47 (HN-LP), and 5.81 (HN-HP). Rhizoboxes were provided with $800 \mathrm{~mL}$ of half Hoagland concentration per rhizobox before transplanting. The composition of the Hoagland solution was adjusted for each N:P stoichiometry level (low/high N, low/high P) (Supplementary table 1). To maintain the osmotic potential, we used $\mathrm{K}_{2} \mathrm{SO}_{4}$ and $\mathrm{CaCl}_{2} \cdot 2 \mathrm{H}_{2} \mathrm{O}$ as a replacement for $\mathrm{KH}_{2} \mathrm{PO}_{4}$, $\mathrm{Ca}\left(\mathrm{NO}_{3}\right)_{2} \cdot 4 \mathrm{H}_{2} \mathrm{O}$ and $\mathrm{KNO}_{3}$ (Supplementary table 1). Rhizoboxes were left to drain for $24 \mathrm{~h}$ and subsequently weighed. For each rhizobox, water loss was estimated as the difference between the mass of a rhizobox at a given time and its mass recorded at the beginning of the experiment.

Harvest and measurements

At harvest, shoots were cut at the base and oven-dried at $80{ }^{\circ} \mathrm{C}$ (for $48 \mathrm{~h}$ ) until a constant mass was reached. 
Fig. 1 Schematic diagram representing barley grown with or without competition in rhizoboxes and showing the rooting depths sampled to assess differential root foraging responses to four N:P stoichiometry levels: low $\mathrm{N}+$ low $\mathrm{P}$, low $\mathrm{N}+$ high $\mathrm{P}$, high $\mathrm{N}+$ low $\mathrm{P}$, and high $\mathrm{N}+$ high $\mathrm{P}$
Without competition (1 plant rhizobox ${ }^{-1}$ )

With competition (3 plants rhizobox ${ }^{-1}$ )

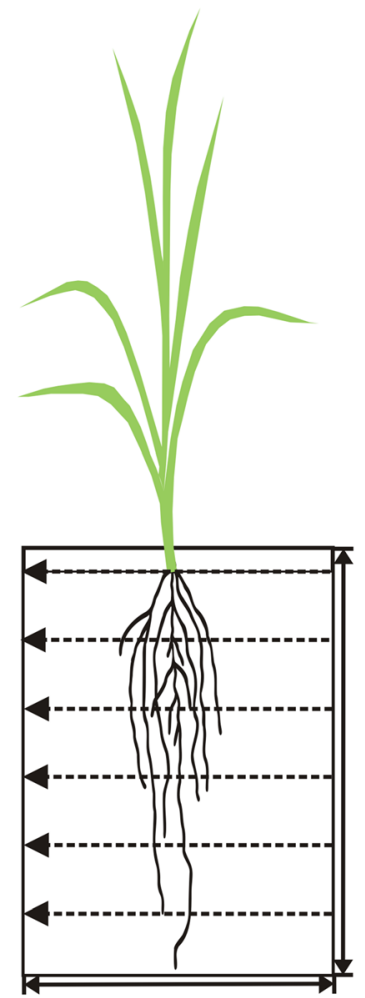

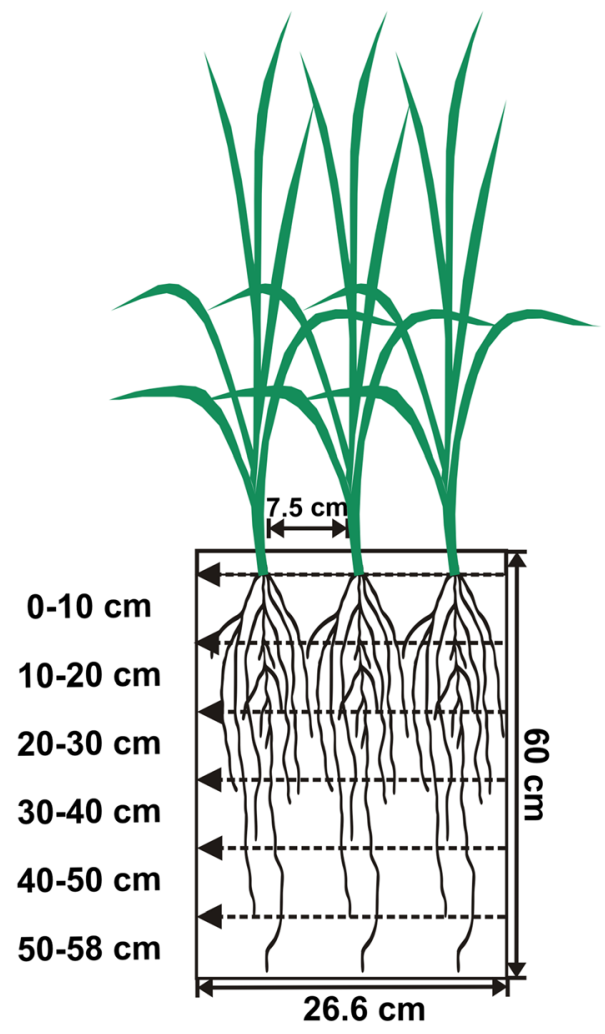

Afterward, we carefully removed the front window of each rhizobox and divided the soil into six $10-\mathrm{cm}$ layers (0-10, 10-20, 20-30, 30-40, 40-50, 50-58 cm). For each soil layer, roots were washed with tap water and stored at $-20^{\circ} \mathrm{C}$ until further measurements. We followed the protocol of Delory et al. (2017) for root trait measurements. Briefly, material adhering to roots was removed with brush and tweezers. In order to improve fine root detection during image analysis, clean roots were stained with a $1.7 \mathrm{mM}$ neutral red solution for $\sim 24 \mathrm{~h}$. Excess stain was removed by continuously rinsing roots with distilled water, and big root segments were cut into small pieces to avoid root overlaps during scanning. Stained roots were spread in a thin layer of distilled water in a transparent tray and scanned at 600 dpi using a commercial scanner (Epson Perfection V800 Photo, Epson, Japan). Scanned images were then analyzed with an image analysis software (WinRhizo, Regent Instruments, Quebec, Canada) using a global threshold method. Interactive modifications to grey level pixel classification were made to improve root detection and root length estimation (Delory et al. 2017). Afterward, roots were dried at $60{ }^{\circ} \mathrm{C}$ (for $48 \mathrm{~h}$ ) until a constant mass was reached. Root mass fraction (RMF) was calculated as the ratio of root biomass to the total plant biomass, and specific root length (SRL) was calculated as root length per unit of root biomass.

All shoot material was ground with a ball mill (MM 400 , Retsch, Germany), and measured for total C and N with an elemental analyzer (Vario EL, Elementar, Germany). For shoot $\mathrm{P}$ concentration, $70 \mathrm{mg}$ ground samples were spiked with $2 \mathrm{~mL} \mathrm{HNO}_{3}(65 \%)$ and $1 \mathrm{~mL}$ $\mathrm{H}_{2} \mathrm{O}_{2}(30 \%)$ before microwave extraction, using a MARS 5 microwave system (CEM GmbH, Germany) at $800 \mathrm{~W}(80 \%)$ power, a linear temperature gradient from RT to $160{ }^{\circ} \mathrm{C}$ in $20 \mathrm{~min}$, holding the end temperature for $15 \mathrm{~min}$. Afterward, each sample was filled up to $14 \mathrm{~mL}$ with ultrapure water. For P concentration determination, two aliquots of the obtained solution were diluted 1:20 with ultrapure water and analyzed. The relative standard deviation between the two repetitions was $\pm 10 \%$. Total $\mathrm{P}$ was measured with 
inductively coupled plasma optical emission spectrometry (iCAPTM 7600 ICP-OES Analyzer, Thermo Scientific, Germany).

Vertical root distribution

The vertical root distribution in each rhizobox was modeled using the following asymptotic equation (Gale and Grigal 1987; Jackson et al. 1996; Oram et al. 2018):

$Y=1-\beta^{d}$

Where $Y$ is the cumulative proportion $[0,1]$ of the total root biomass located above depth $d$ (in this case 0 $58 \mathrm{~cm}$ ), and $\beta$ is a fitted model parameter used as a simple numerical index of vertical root distribution (Schnepf et al. 2019). Lower $\beta$ values correspond to higher root mass allocation to surface layers, whereas higher values correspond to higher root mass allocation to deeper soil strata (Fig. 2).

\section{Statistical analyses}

All statistical analyses were performed in R 3.5.0 ( $\mathrm{R}$ Core Team 2018) and graphs were prepared with 'ggplot2' library (Wickham 2016) and R-base. We followed the protocol for data exploration in Zuur et al. (2010). Potential outliers were detected using a combination of boxplots and Cleveland plots. Presented in graphs are mean values of 5 replicates (4 replicates for specific root length except for LN-HP where $n=5) \pm$ standard error (SE). Two-way ANOVA models were used to test if N:P stoichiometry, intraspecific competition, and their interaction affected shoot and root biomass, vertical root distribution $(\beta)$, specific root length, and shoot $\mathrm{N}$ and $\mathrm{P}$ concentrations. Residual plots were visually checked for any mean-variance relationship ("V shape"). As we did not observe any pattern suggesting heteroscedasticity in our data, we did not transform the data prior to analysis. Pairwise comparisons were performed on estimated marginal means computed by lsmeans using Tukey contrasts (lsmeans; Lenth 2016). In case there was no interaction between N:P stoichiometry and competition, we show only N:P stoichiometry effects (for shoot biomass and shoot $\mathrm{P}$ concentration). The linear relationship between shoot $\mathrm{N}$ concentration and specific root length was analyzed using standard major axis (SMA) regression using the smatr

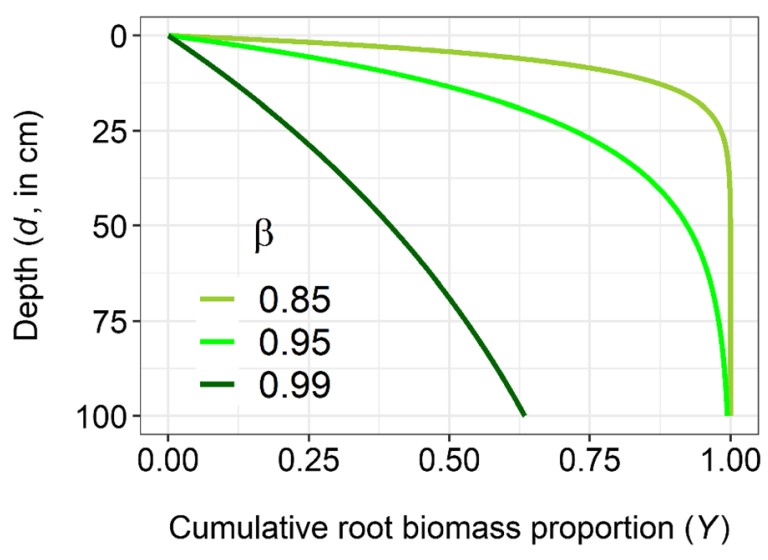

Fig. 2 Cumulative root biomass distribution as a function of soil depth as per Gale and Grigal (1987). Higher $\beta$ values imply that a greater proportion of root biomass is located in deeper soil layers, whereas lower $\beta$ values imply that a greater proportion of root biomass is located in shallower soil layers

package (Warton et al. 2012). SMA regression examines the relationship between two variables that are both measured with errors (Warton et al. 2012).

\section{Results}

Shoot biomass

Both N:P stoichiometry $\left(\mathrm{F}_{3,32}=53.08, P<0.001\right)$ and competition $\left(\mathrm{F}_{1,32}=52.07, P<0.001\right)$ had a significant effect on shoot biomass (per plant) production. The effect of N:P stoichiometry did not depend on the level of intraspecific competition $\left(\mathrm{F}_{3,32}=0.48, P=0.69\right)$. Looking at the effect of N:P stoichiometry, shoot biomass (per plant) increased in the following order: LN$\mathrm{LP}<\mathrm{LN}-\mathrm{HP}<\mathrm{HN}-\mathrm{LP}<\mathrm{HN}-\mathrm{HP}$. Compared to LN-LP, shoot biomass was on average $12 \%, 32 \%$, and $58 \%$ greater under LN-HP, HN-LP, and HN-HP, respectively (Fig. 3a). For plants grown in the presence of competitors, shoot biomass was on average $22 \%$ lower than plants grown in the absence of competition.

\section{Root system responses}

Even though the greater amount of either N, P, or both increased shoot biomass, neither $\mathrm{N}: \mathrm{P}$ stoichiometry $\left(\mathrm{F}_{3,32}=0.79, P=0.51\right)$ nor competition $\left(\mathrm{F}_{1,32}=1.49\right.$, $P=0.24)$ had an effect on total root biomass production (per plant) (Fig. 3b). However, biomass allocation as measured by the RMF was affected by $\mathrm{N}: \mathrm{P}$ 
stoichiometry $\left(\mathrm{F}_{3,32}=32.62, P<0.001\right)$, competition $\left(\mathrm{F}_{1,32}=26.01, P<0.001\right)$, and their interaction $\left(\mathrm{F}_{3,32}=\right.$ $5.77, P=0.002)$. Irrespective of the presence or absence of competition, RMF was greater when both $\mathrm{N}$ and $\mathrm{P}$ were provided in low amounts (LN-LP) (Fig. 4). A high amount of either N, P, or both decreased RMF when plants were grown without competition. In contrast, when plants were grown in competition, providing high $\mathrm{P}$ (LN-HP) had no effect on RMF as compared to LNLP (Fig. 4). In addition, providing high $\mathrm{N}$ with low or high $\mathrm{P}$ (HN-LP and HN-HP) reduced RMF both in the presence and absence of competitors.

Vertical root distribution $(\beta)$ was affected differently across N:P stoichiometry levels for plants growing alone or in competition (N:P stoichiometry: $\mathrm{F}_{3,32}=22.19, P<0.001$; competition: $\mathrm{F}_{1,32}=59.46$, $P<0.001 ; \mathrm{N}: \mathrm{P}$ stoichiometry $\times$ competition: $\mathrm{F}_{3,32}=$ $4.85, P=0.006$ ). Vertical root distribution was governed by the identity of the nutrient being the most limiting (either N, P, or both) only for individually grown barley plants (in absence of competition). Without competition, a greater proportion of root biomass was found in deeper soil layers (greatest $\beta$ value) when both $\mathrm{N}$ and $\mathrm{P}$ were provided in low amounts (LN-LP). On average, plants grown without competition in the LN-HP treatment also had a greater proportion of root biomass deeper in the soil as compared to HN-LP and HN-HP treatments (Fig. 5a). Interestingly, the presence of competitors had a strong effect on the vertical root distribution. In this situation, the identity of the nutrient being the most limiting did not have any impact on root distribution. Overall, plants tended to increase root biomass allocation to deeper soil layers (greater $\beta$ values) when growing in competition (Fig. 5a, see supplementary Fig. 2 for depth-wise root biomass).

Even though the belowground biomass production remained similar between experimental treatments, root morphology was clearly impacted. Specific root length (SRL) was affected by N:P stoichiometry $\left(\mathrm{F}_{3,32}=7.06, P=0.001\right)$ and interacted with competition $\left(\mathrm{F}_{3,32}=5.70, P=0.003\right)$, but competition alone had no effect on SRL (Fig. 5b). Without competition, SRL was greater when either N, P, or both were provided in low amounts and did not depend on the identity of the nutrient being the most limiting. In contrast, in the presence of competition, SRL was greater only when $\mathrm{P}$ was the only limiting nutrient (HN-LP) (Fig. 5b).
Shoot N:P concentrations

$\mathrm{N}: \mathrm{P}$ stoichiometry and competition (presence/absence) had distinct effects on shoot $\mathrm{N}$ and $\mathrm{P}$ concentrations. Providing more N (HN-LP and HN-HP) or more P (LN$\mathrm{HP}$ and $\mathrm{HN}-\mathrm{HP}$ ) resulted in greater shoot $\mathrm{N}$ and $\mathrm{P}$ concentrations, respectively. Shoot $\mathrm{N}$ concentration was significantly altered by $\mathrm{N}: \mathrm{P}$ stoichiometry $\left(\mathrm{F}_{3,32}=\right.$ 222.9, $P<0.001)$, competition $\left(\mathrm{F}_{1,32}=259.3\right.$, $P<0.001)$, and their interaction $\left(\mathrm{F}_{3,32}=10.9\right.$, $P<0.001$ ) (Fig. 6a). Without competition, shoot $\mathrm{N}$ remained similar for both HN-LP and HN-HP, whereas, in the presence of competition, plant shoots had a greater N concentration under HN-LP than HN-HP (Fig. 6a). On the other hand, shoot $\mathrm{P}$ concentration was altered only by $\mathrm{N}: \mathrm{P}$ stoichiometry $\left(\mathrm{F}_{3,32}=9.19, P<0.001\right)$. Providing more $\mathrm{P}$ increased its concentration in shoots on average by $53 \%$ (LN-HP) and 42\% (HN-HP) (Fig. $6 \mathrm{~b})$. Our results also showed the existence of a positive correlation between SRL and shoot $\mathrm{N}$ concentration $\left(\mathrm{R}^{2}=0.51 ; P=0.001\right)$, but only under intraspecific competition (Fig. 7). Further, shoot $\mathrm{N}: \mathrm{P}$ mass ratio was affected by $\mathrm{N}: \mathrm{P}$ stoichiometry $\left(\mathrm{F}_{3,32}=21.72, P<0.001\right)$ and competition $\left(\mathrm{F}_{1,32}=5.50, P=0.025\right)$. Compared to LN-LP, lower shoot N:P values were observed when $\mathrm{N}$ was the only limiting nutrient, while greater shoot N:P values were observed when $\mathrm{P}$ was the only limiting nutrient in the soil solution (Supplementary Fig. 1). Shoot N:P ratios decreased from $24.6 \pm 2.3$ to $20.1 \pm$ 2.1 in the presence of intraspecific competition.

\section{Discussion}

Shoot but not root biomass production is more limited by $\mathrm{N}$ than by $\mathrm{P}$

There is a general consensus that plants respond to nutrient shortage by changing their allocation patterns both below- and aboveground (Hermans et al. 2006). When the availability of both macronutrients was low (LN-LP), aboveground productivity was the lowest, indicative of nutrient limitation. On the other hand, providing extra $\mathrm{P}$ or not, did not increase the shoot biomass production if $\mathrm{N}$ was the limiting nutrient (both in LN-LP and LN-HP), highlighting higher $\mathrm{N}$ demand for biomass production and supports synergistic response to $\mathrm{N}$ and $\mathrm{P}$ availability (Harpole et al. 2011). Leaf $\mathrm{N}$ content is generally related to $\mathrm{C}$ assimilation 

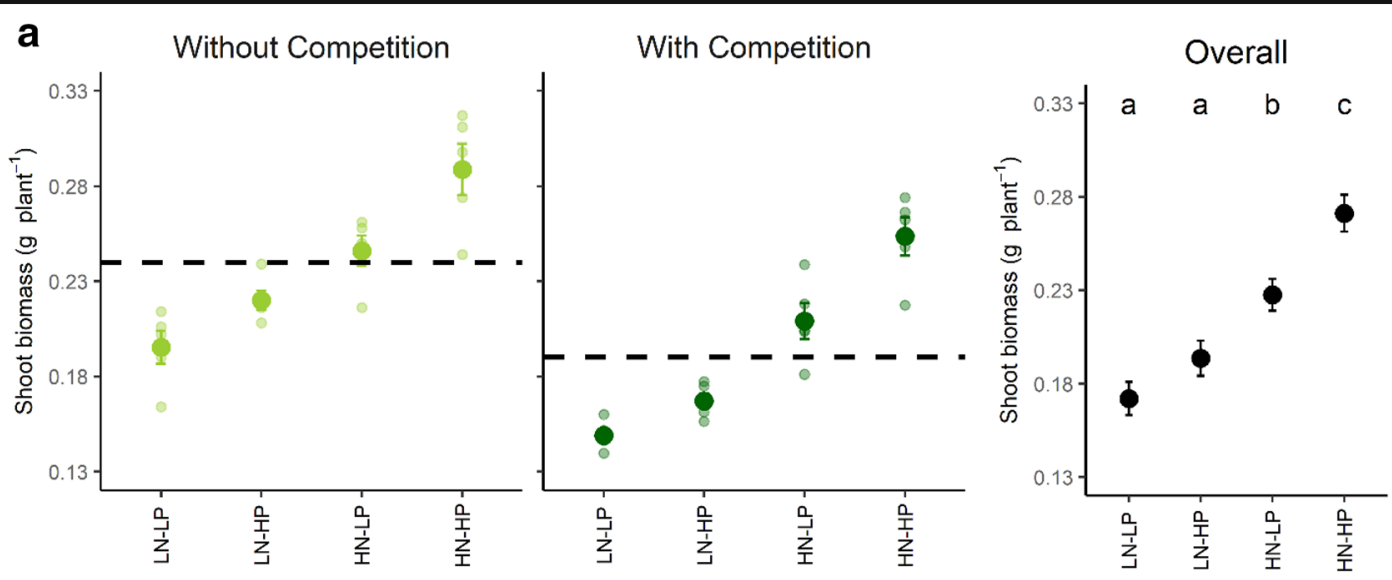

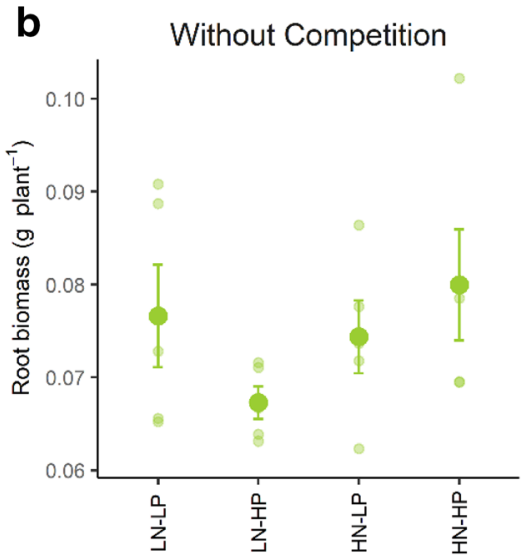

Fig. 3 a) Shoot and b) root biomass (g plant ${ }^{-1} \pm$ SE) across N:P stoichiometry and with and without competition. LN-LP: low $\mathrm{N}$ and low P, LN-HP: low N and high P, HN-LP: high N and low P, and HN-HP: high $\mathrm{N}$ and high P. For shoot biomass, there was no interaction between $\mathrm{N}: \mathrm{P}$ stoichiometry and competition. Therefore, a graph showing the results for each N:P stoichiometry level
With Competition

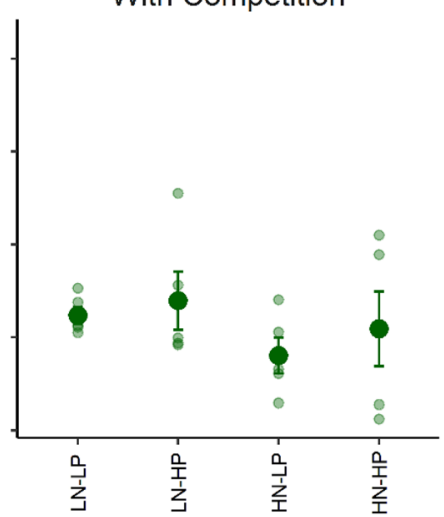

(across competition levels) is also displayed. For shoot biomass, dashed lines show mean shoot biomass values without and with competition. Different letters indicate significant differences (Tukey's post-hoc, $P<0.05$ ) between N:P stoichiometry levels only during photosynthesis (Gastal and Lemaire 2002). If reduced leaf $\mathrm{N}$ content leads to a reduction in the plant's photosynthetic activity, a lower shoot biomass production can be expected when $\mathrm{N}$ is limiting in the soil (Fig. 1). Andrews et al. (1999) showed for Pisum sativum, Triticum aestivum, and Phaseolus vulgaris that $\mathrm{N}$ shortage effects on plant growth are through its effects on protein synthesis. This further demonstrates that $\mathrm{N}$ limitation is more severe than $\mathrm{P}$ limitation for plant growth (see Čapek et al. 2018) as the availability of extra P (LNHP) in our study did not lead to higher shoot biomass production, probably due to $\mathrm{N}$-mediated decrease in photosynthetic activity. Increased availability of both $\mathrm{N}$ and $\mathrm{P}$ (HN-HP), on the other hand, resulted in the greatest shoot biomass production because of greater $\mathrm{N}$ and $\mathrm{P}$ uptake that might ultimately lead to higher photosynthetic activity (Kumar et al. 2019).

Interestingly, root biomass production remained similar across N:P stoichiometry levels, but the RMF was greater when both $\mathrm{N}$ and $\mathrm{P}$ availability was low (LN-LP) in the absence of competition. This follows the general plant response to increasing $\mathrm{C}$ investment belowground when nutrient availability in the environment is low (Poorter et al. 2012).

Nutrient availability can strongly direct resource allocation patterns in plants (Gastal and Lemaire 2002). More $\mathrm{C}$ allocation to roots under low nutrient availability is a well-known plant response as a potential mechanism to optimize growth by exploring a greater proportion of the soil volume for nutrients (De Groot et al. 


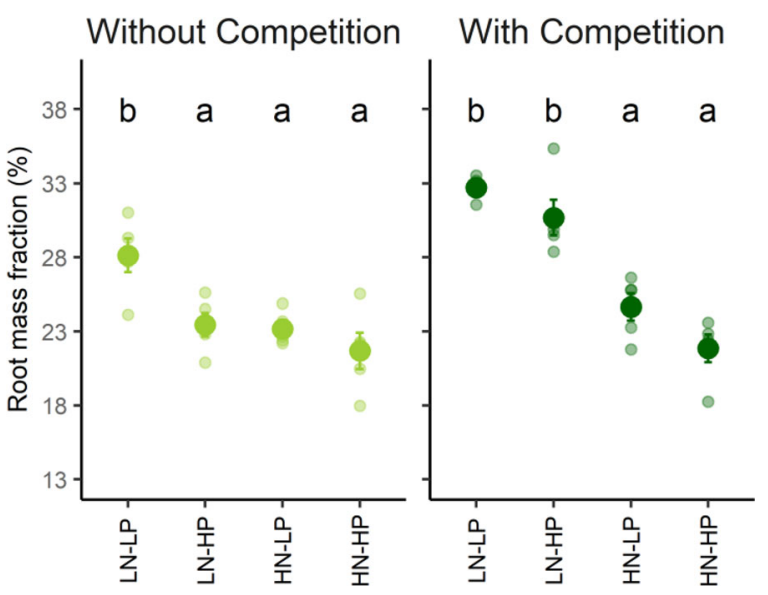

Fig. 4 Root mass fraction (\%) across N:P stoichiometry and with and without competition. LN-LP: low N and low P, LN-HP: low N and high P, HN-LP: high $\mathrm{N}$ and low $\mathrm{P}$, and HN-HP: high $\mathrm{N}$ and high $\mathrm{P}$. For each competition level, different letters indicate significant differences (Tukey's post-hoc test, $P<0.05$ ) between N:P stoichiometry levels

2003; Hermans et al. 2006; Lambers et al. 2006). This is in line with optimal resource allocation theory, which predicts higher resource partitioning in organs that maximize the plant growth (Bloom et al. 1985). Increased RMF due to nutrient shortage allows plants to forage more effectively, yet it trades off with resource allocation in shoot biomass production (Garnett et al. 2009). We are aware that RMF only provides information about resource allocation to root growth component and does not necessarily include other carbon investments such as root respiration and exudation, yet it provides a hint about plant investments belowground for nutrient foraging. Greater availability of both $\mathrm{N}$ and $\mathrm{P}$ (HN-HP) has potentially led to lower investment belowground as shown in various studies for different vegetation (Aerts et al. 1991; Klimeš and Klimešová 1994; Wright et al. 2014). This further supports the notion of preferential uptake of available nutrients by roots, thereby minimizing their resource investments belowground for nutrient acquisition. These findings partly support our first hypothesis as the response to $\mathrm{N}$ limitation was only seen for the shoot but not root biomass.

Intraspecific competition reduces shoot but not root biomass production

It has been shown that plant-plant competition decreases the total biomass production both for interspecific
(Heuermann et al. 2019) and intraspecific competition (Zhou et al. 2018). We also showed that shoot biomass decreased in the presence of competition. A common underlying reason for this decline in biomass production when plants are competing is due to quick uptake of available nutrients leading to soil nutrient shortage (Tilman 1990; Craine and Dybzinski 2013). Surprisingly, we did not observe any change in root biomass production with or without competition. When plants are competing, and if plant growth is mostly affected by nutrient availability in soil, we would expect a greater resource investment in belowground organs to enhance nutrient uptake. In the presence of competition, a strong decrease in shoot biomass without altering root biomass per plant is confirmatory of increasing competitive ability for belowground resources, but at the expense of shoot biomass production. This also hints towards the plant's phenotypic plasticity in biomass partitioning between shoots and roots. Since the duration of our experiment was short and the plants were of the same age and size when grown in competition (3 plants rhizobox ${ }^{-1}$ ), we believe that aboveground competition (which is usually size-asymmetric) was low in this study (Weiner and Thomas 1986). According to the competition model for limiting resources (Van Wijk et al. 2003), a lower investment belowground cannot sustain plant growth due to lower nutrient availability when plants are competing with each other. To maintain growth, therefore, higher investment in roots should be favored. In a recent study focusing on interspecific competition (growing oat with clover), increased root to shoot ratio without affecting shoot biomass production highlights that competition favored root biomass production for nutrient access (Heuermann et al. 2019). Further, the observed increase in RMF without affecting total root biomass under low $\mathrm{N}$ availability (LN-LP and LN-HP) supports our first hypothesis that $\mathrm{N}$ is more limiting plant growth than $\mathrm{P}$ limitation. Secondly, our second hypothesis is partly supported as only shoot biomass but not root biomass decreased with the intraspecific competition.

Root biomass allocation to deeper soil layers increased under $\mathrm{N}$ limitation, but only when growing without competitors

Root biomass may not always be indicative of the absorptive capacity of roots, and significant modifications in root morphology, anatomy, and architecture are possible with or without altering the total root biomass (Hodge 2004). In our study, although the total root biomass remained similar 
Fig. 5 a) Vertical root distribution ( $\beta \pm \mathrm{SE}$, see methods) and b) specific root length $\left(\mathrm{m} \mathrm{g}^{-1} \pm \mathrm{SE}\right)$ across $\mathrm{N}: \mathrm{P}$ stoichiometry and with and without competition. LN-LP: low $\mathrm{N}$ and low P, LN-HP: low N and high P, HN-LP: high N and low $\mathrm{P}$, and HN-HP: high $\mathrm{N}$ and high $\mathrm{P}$. For each competition level, different letters indicate significant differences (Tukey's post-hoc test, $P<0.05$ ) between $\mathrm{N}: \mathrm{P}$ stoichiometry levels
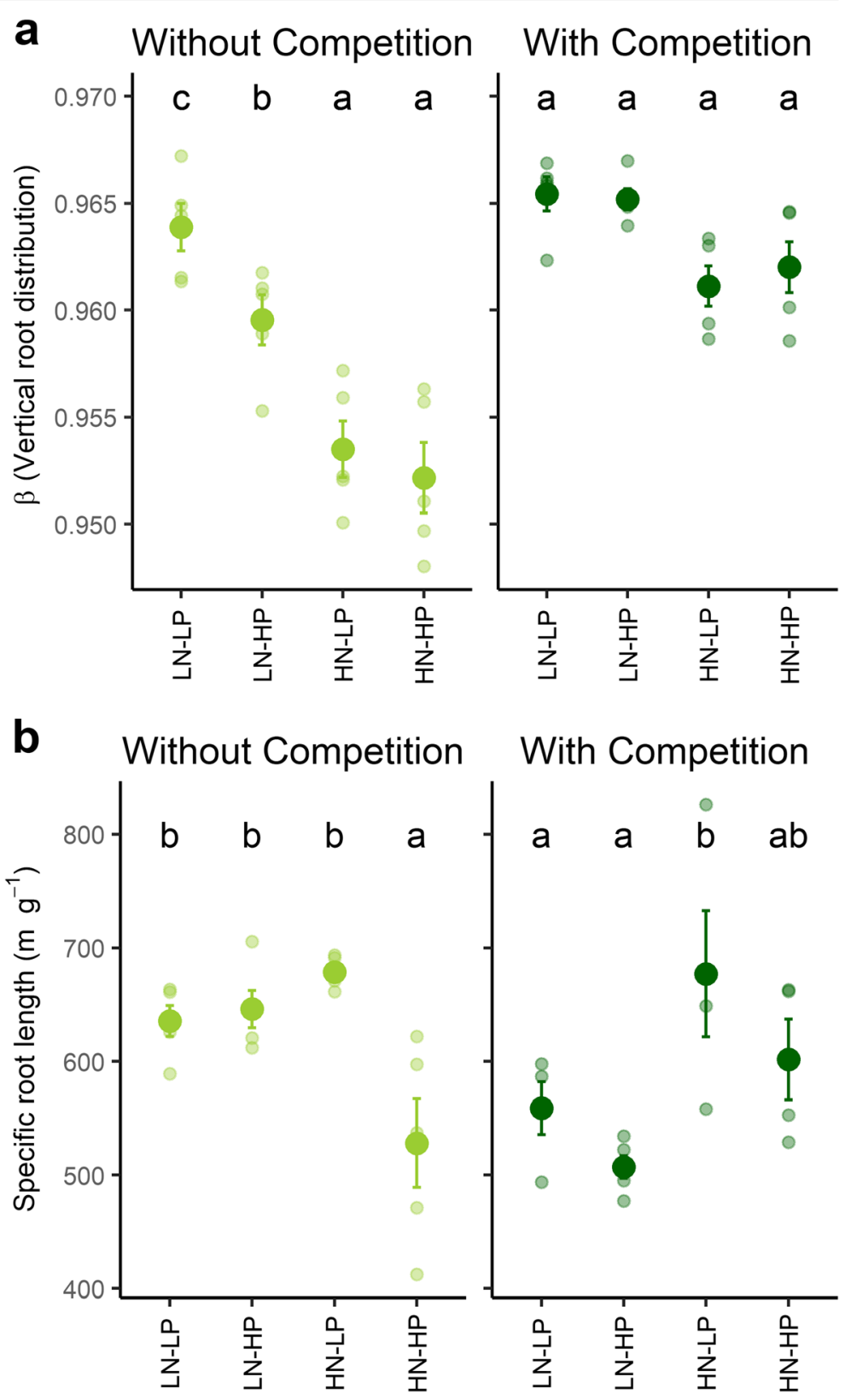

between experimental treatments, we showed that the effect of N:P stoichiometry affected root system responses differently depending on the presence or absence of competitors. Such root system responses can be driven by relative mobility and, therefore, availability of $\mathrm{N}$ and $\mathrm{P}$ in soil strata. Vertical root distribution depended strongly on the identity of the limiting nutrient (either N, P, or both) in the absence of competition. For example, plants invested more root biomass in top soil layers (lower $\beta$ value) when $\mathrm{P}$ availability was low (HN-LP) whereas this allocation shifted to deeper soil layers (higher $\beta$ value) when $\mathrm{N}$ was the most limiting nutrient (LN-HP). Interestingly, when both nutrients were limiting (LN-LP), $\beta$ was greatest thus suggesting that vertical root distribution was more likely driven by $\mathrm{N}$ limitation than $\mathrm{P}$ limitation and higher $\mathrm{N}$ than $\mathrm{P}$ demand. Given that $\mathrm{P}$ is less mobile than $\mathrm{N}$ in the soil matrix (Harrison 1987), we expect more $P$ to be present in the topsoil and more $\mathrm{N}$ to be present in deeper soil layers, and their relative limitations may have guided root responses. Plants respond to $\mathrm{P}$ shortage by reducing the primary root 


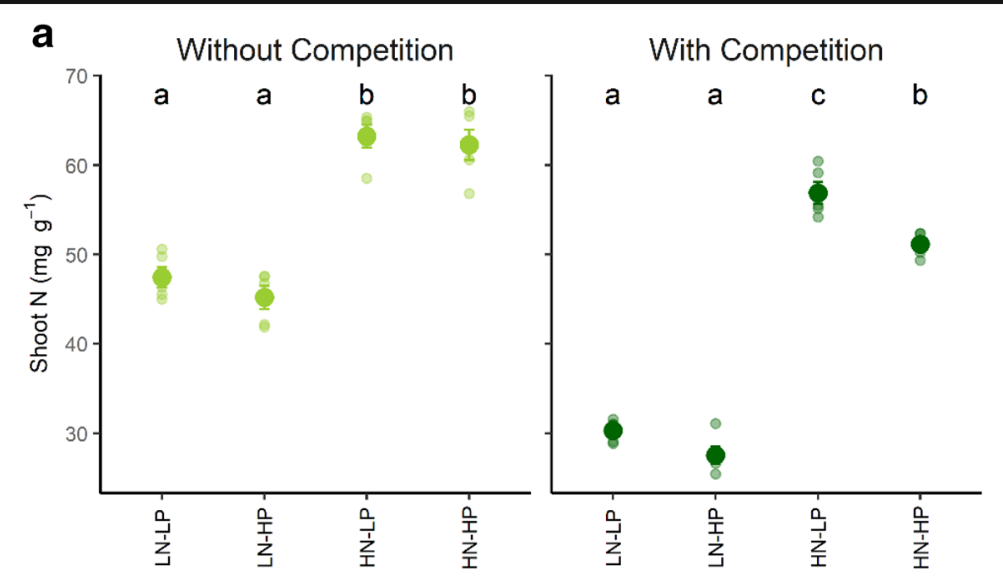

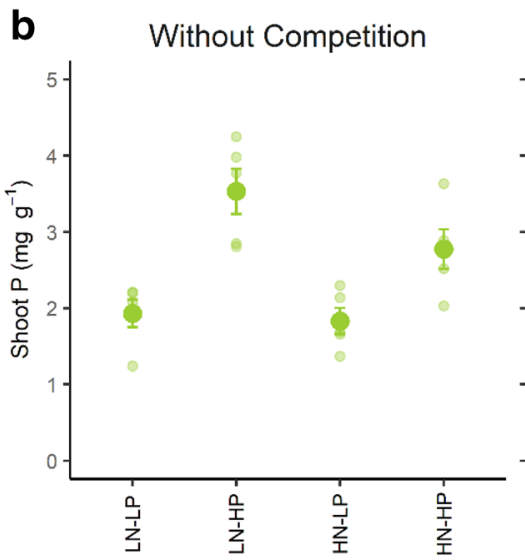

Fig. 6 a) Shoot $\mathrm{N}$ and b) shoot $\mathrm{P}\left(\mathrm{mg} \mathrm{g}^{-1} \pm \mathrm{SE}\right)$ across $\mathrm{N}: \mathrm{P}$ stoichiometry and with and without competition. LN-LP: low N and low P, LN-HP: low N and high P, HN-LP: high N and low P, and HN-HP: high $\mathrm{N}$ and high $\mathrm{P}$. For shoot $\mathrm{P}$, there was no interaction between N:P stoichiometry and competition. Therefore, a graph showing the results for each $\mathrm{N}: \mathrm{P}$ stoichiometry level

elongation but an increased number of lateral roots (Vance et al. 2003; Sánchez-Calderón et al. 2005). Further, Jia et al. (2018) showed that increasing the lateral root branching enhanced maize P acquisition. Gruber et al. (2013) also showed a shallower yet highly branched root system for Arabidopsis under $\mathrm{P}$ deficiency. On the other hand, when $\mathrm{N}$ is limiting plant growth, the plant's investment in deep root systems is favored (Koevoets et al. 2016). In the presence of competition, $\beta$ values did not change across N:P stoichiometry levels. Competition most likely resulted in faster depletion of nutrients in soil through plant uptake. Therefore, roots foraged throughout the rhizobox to their maximum extent to get access to both $\mathrm{N}$ and $\mathrm{P}$. In support of our third hypothesis, we show that plants root deeper when $\mathrm{N}$ is the most limiting nutrient, whereas shallower when $\mathrm{P}$ is the most limiting nutrient, but only in the absence of
With Competition

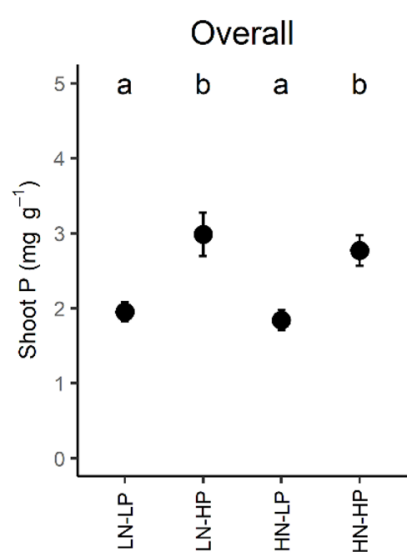

(across competition levels) is also displayed. For shoot N, different letters indicate significant differences (Tukey's post-hoc test, $P<0.05)$ between N:P stoichiometry levels for each competition scenario. For shoot $\mathrm{P}$, different letters indicate significant differences (Tukey's post-hoc test, $P<0.05$ ) between N:P stoichiometry levels across competition scenarios

competition. Further, in the presence of intraspecific competition, root foraging is modulated by deeper soil exploration.

We also showed that, in the absence of competition, the SRL was greater when either N, P, or both were available in low amounts relative to HN-HP (Fig. 5b). Changes in SRL are general root morphological responses to lower availability of nutrients in the soil (Kong et al. 2014). By increasing SRL without altering the overall root biomass, plants are able to increase their foraging capacity. However, this may also be an apparent strategy of plants for nutrient acquisition as thinner roots have a lower life span and faster turnover (McCormack et al. 2012). On the contrary, when both $\mathrm{N}$ and $\mathrm{P}$ are not limiting plant growth (under HN-HP), it is more favorable for plants to invest less in increasing SRL due to associated aboveground 


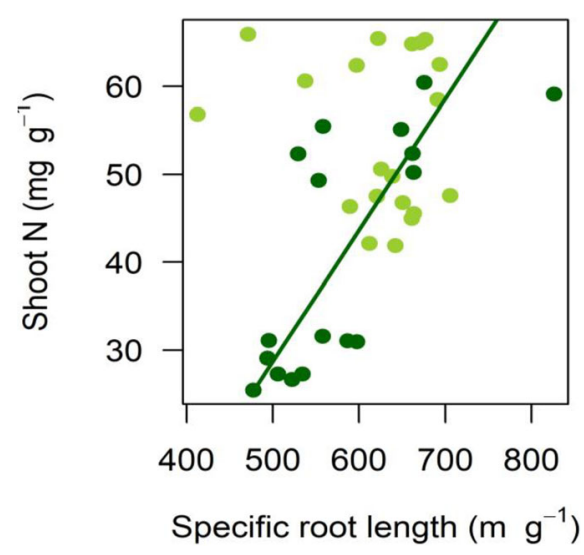

Fig. 7 Linear relationship between specific root length $\left(\mathrm{m} \mathrm{g}^{-1}\right)$ and shoot $\mathrm{N}$ concentration $\left(\mathrm{mg} \mathrm{g}^{-1}\right)$. Light green circles represent absence whereas dark green circles represent presence of competition, respectively. Regression line between shoot $\mathrm{N}$ and specific root length is shown only when competition was present (for dark green)

allocation trades off. We expected the same effect of N:P stoichiometry on SRL in the presence of competition. However, we found contrasting effects, and SRL was lower when only $\mathrm{N}$ (LN-HP) or both $\mathrm{N}$ and P (LN-LP) were available in low amounts, whereas it increased only under HN-LP (high N but low P availability). As P is less mobile than $\mathrm{N}$ in the soil, increasing $\mathrm{P}$ foraging by greater SRL is likely one efficient strategy to increase its uptake. In contrast, greater $\mathrm{N}$ mobility would rather result in a deeper rooting system than increasing SRL locally to increase its uptake efficiently. Greater SRL with low P but high N availability (HN-LP) resulted in higher shoot $\mathrm{N}$ concentration and associated higher $\mathrm{P}$ requirement. However, increased SRL did not result in higher shoot $\mathrm{P}$ concentration due to its low availability. This further explains the positive relationship between SRL and shoot $\mathrm{N}$ concentration (probably as an indirect consequence of $\mathrm{P}$ limitation) (Fig. 7). These findings contrast strongly with results from a study in grasslands by Mommer et al. (2010), where interspecific competition with neighbors caused both higher investment of plants in root biomass as well as an accumulation of roots in the topsoil. This contrasting result could be driven by differences in root responses depending on whether neighbors are of the same or different species. Clearly, the presence of neighbors, whether of the same species or not, can drive this partly unexpected responses of roots. Whether experimental conditions are controlled (in the greenhouse) or not (in the field) will also probably affect the outcome.
Effect of $\mathrm{N}: \mathrm{P}$ stoichiometry and competition on shoot $\mathrm{N}$ and $\mathrm{P}$ concentrations

Shoot $\mathrm{N}$ and $\mathrm{P}$ concentrations were in line with what was expected. Providing high N (HN-LP and HN-HP) or high $\mathrm{P}$ (LN-HP and HN-HP) resulted in greater $\mathrm{N}$ and $\mathrm{P}$ concentrations in shoots, respectively. Intriguingly, in the presence of competition, we found that when both $\mathrm{N}$ and $\mathrm{P}$ availability was high (HN-HP), shoot $\mathrm{N}$ concentration was slightly lower than in plants grown under high $\mathrm{N}$ and low P (HN-LP) availability. This can most likely be explained by the fact that when both $\mathrm{N}$ and $\mathrm{P}$ were high, plants grew better (higher shoot biomass under HN-HP than HN-LP) and, as a consequence, exacerbated greater $\mathrm{N}$ demand. On the other hand, shoot $\mathrm{P}$ concentration was driven only by its availability in the soil and was similar for both with or without competition. This further supports our first hypothesis that soil $\mathrm{N}$ availability has a stronger effect in regulating plant performance more than $\mathrm{P}$.

\section{Conclusions}

Plant responses to soil nutrient availability and plant-plant competition are decisive for plant performance. Lower shoot biomass under low $\mathrm{N}$ availability irrespective of $\mathrm{P}$ availability (both for LN-LP and LN-HP) indicates $\mathrm{N}$ limitation for shoot biomass production most likely due to higher $\mathrm{N}$ demand for photosynthesis. Higher investments belowground as a response to nutrient limitation pose a tradeoff with shoot biomass production. Roots foraged differently for $\mathrm{N}$ or $\mathrm{P}$ uptake. A greater proportion of the total root biomass was found deeper in the soil when $\mathrm{N}$ was limiting, while a greater proportion of the root biomass was found closer to the soil surface when $\mathrm{P}$ was limiting plant growth. However, when plants were competing for $\mathrm{N}$ and $\mathrm{P}$ in soil solution, no decrease in root biomass but lower shoot biomass per plant indicated differential resource allocation pattern by plants for maximizing nutrient uptake. When competing, plants rooted deeper indicating higher $\mathrm{N}$ demand and associated root acquisition strategy under these conditions. Such shift in plant resource allocation and root growth are key determinants for early plant nutrient acquisition and establishment, and illustrate the importance of biotic as well as abiotic drivers of plant responses to their environment. Field studies that manipulate N:P stoichiometry and focus on root foraging responses would move the field further forward now. 
Acknowledgments We thank Thomas Niemeyer for greenhouse assistance, Saatzucht Breun for supplying barley seeds free of charge, Dr. Kathleen Lemanski and Prof. Michael Bonkowski for arranging the Jackerath loess soil, Hannes Schempp, Hannah Uther, Johanna Wille, and IAESTE students for root scanning and laboratory assistance. We thank the handling editor and two anonymous reviewers whose comments and suggestions helped us to improve the quality of this manuscript.

Funding Information Open Access funding provided by Projekt DEAL. This work was supported by the BonaRes soil sustainability program of the Federal German Ministry for Education and Research (BMBF) for funding this research within the 'INPLAMINT - Increasing agricultural nutrient-use efficiency by optimizing plant-soil-microorganism interactions' project [grant numbers: $031 \mathrm{~A} 561 \mathrm{~A}, 031 \mathrm{~A} 561 \mathrm{H}, 031 \mathrm{~B} 0508 \mathrm{~A}$, 031B0508H].Data availabilityRaw data and R scripts used for data analyses can be freely accessed at https://doi.org/10.5281 /zenodo.3613623

Open Access This article is licensed under a Creative Commons Attribution 4.0 International License, which permits use, sharing, adaptation, distribution and reproduction in any medium or format, as long as you give appropriate credit to the original author(s) and the source, provide a link to the Creative Commons licence, and indicate if changes were made. The images or other third party material in this article are included in the article's Creative Commons licence, unless indicated otherwise in a credit line to the material. If material is not included in the article's Creative Commons licence and your intended use is not permitted by statutory regulation or exceeds the permitted use, you will need to obtain permission directly from the copyright holder. To view a copy of this licence, visit http://creativecommons.org/licenses/by/4.0/.

\section{References}

Aerts R, Boot RGA, van der Aart PJM (1991) The relation between above- and belowground biomass allocation patterns and competitive ability. Oecologia 87:551-559. https://doi.org/10.1007/BF00320419

Andrews M, Sprent JI, Eady PE (1999) Relationships between shoot to root ration, growth and leaf soluble protein concentration of Pisum sativum, Phaseolus vulgaris and Triticum aestivum under different nutrient deficiencies. Plant Cell Environ 22:949-958.58

Bennett JA, Riibak K, Tamme R et al (2016) The reciprocal relationship between competition and intraspecific trait variation. J Ecol 104:1410-1420. https://doi.org/10.1111/1365-2745.12614

Bloom J, Stuart F, Mooney A (1985) Resource limitation in plantsan economic analogy. Annual Reviews of Ecology and Systematics 16:363-392

Cahill JF, McNickle GG, Haag JJ et al (2010) Plants integrate information about nutrients and neighbors. Science (80- ) 328:1657. https://doi.org/10.1126/science.1189736

Čapek P, Manzoni S, Kaštovská E et al (2018) A plant-microbe interaction framework explaining nutrient effects on primary production. Nat Ecol Evol 2:1588-1596. https://doi. org/10.1038/s41559-018-0662-8
Cornelissen JHC, Werger MJA, Castro-Diez P, van Rheenen JWA, Rowland (1997) Foliar nutrients in relation to growth, allocation and leaf traits in seedlings of a wide range of woody plant species and types. Oecologia 111:569-588

Craine JM, Dybzinski R (2013) Mechanisms of plant competition for nutrients, water and light. Funct Ecol 27:833-840. https://doi.org/10.1111/1365-2435.12081

De Groot CC, Marcelis LFM, Van Den Boogaard R et al (2003) Interaction of nitrogen and phosphorus nutrition in determining growth. Plant Soil 248:257-268. https://doi.org/10.1023 /A:1022323215010

Delory BM, Weidlich EWA, Meder L et al (2017) Accuracy and bias of methods used for root length measurements in functional root research. Meth Ecol Evol 1594-1606. https://doi. org/10.1111/2041-210X.12771

Elser JJ, Fagan WF, Kerkhoff AJ, Swenson NG, Enquist BJ (2010) Biological stoichiometry of plant production: metabolism, scaling and ecological response to global change. New Phytol 186:593-608

Faget M, Nagel KA, Walter A et al (2013) Root-root interactions: extending our perspective to be more inclusive of the range of theories in ecology and agriculture using in-vivo analyses. Ann Bot 112:253-266. https://doi.org/10.1093/aob/mcs296

Fransen B, Berendse F (1998) Root morphological plasticity and nutrient acquisition of perennial grass species from habitats of different nutrient availability. Oecologia 112:351-358

Gale MR, Grigal DF (1987) Vertical root distributions of northern tree species in relation to successional status. Can J For Res 17:829-834

Garnett T, Conn V, Kaiser BN (2009) Root based approaches to improving nitrogen use efficiency in plants. Plant Cell Environ 32:1272-1283. https://doi.org/10.1111/j.13653040.2009.02011.x

Gastal F, Lemaire G (2002) N uptake and distribution in crops: an agronomical and ecophysiological perspective. J Exp Bot 53: 789-799. https://doi.org/10.1093/jexbot/53.370.789

Gruber BD, Giehl RFH, Friedel S, von Wirén N (2013) Plasticity of the Arabidopsis root system under nutrient deficiencies. Plant Physiol 163:161-179. https://doi.org/10.1104/pp.113.218453

Guo H, York L (2019) Reallocation to lateral and early-emerging axial roots allows maize (Zea mays L.) with reduced nodal root number to more efficiently forage for nitrate. J Exp Bot 1-37. https://doi.org/10.1101/533042

Güsewell S (2004) N:P ratios in terrestrial plants: variation and functional significance. New Phytol 164:243-266. https://doi.org/10.1111/j.1469-8137.2004.01192.x

Harpole WS, Ngai JT, Cleland EE et al (2011) Nutrient co-limitation of primary producer communities. Ecol Lett 14:852862. https://doi.org/10.1111/j.1461-0248.2011.01651.x

Harrison AF (1987) Soil organic phosphorus: a review of world literautre. CAB international, Wallongford

He JS, Wang L, Flynn DBF, Wang X, Ma W, Fang J (2008) Leaf nitrogen:phosphorus stoichiometry across Chinese grassland biomes. Oecologia 155:301-310. https://doi.org/10.1007 /s00442-007-0912-y

Hecht VL, Temperton VM, Nagel KA et al (2019) Plant density modifies root system architecture in spring barley (Hordeum vulgare L.) through a change in nodal root number. Plant Soil 439:179-200. https://doi.org/10.1007/s11104-018-3764-9

Hecht VL, Temperton VM, Nagel KA, Rascher U (2016) Sowing density : a neglected factor fundamentally affecting root 
distribution and biomass allocation of field grown spring Barley (Hordeum vulgare L.). 7:1-14. https://doi.org/10.3389 /fpls.2016.00944

Hermans C, Hammond JP, White PJ, Verbruggen N (2006) How do plants respond to nutrient shortage by biomass allocation? Trends Plant Sci 11:610-617. https://doi.org/10.1016/j. tplants.2006.10.007

Heuermann D, Gentsch N, Boy J et al (2019) Interspecific competition among catch crops modifies vertical root biomass distribution and nitrate scavenging in soils. Sci Rep 9:1-11. https://doi.org/10.1038/s41598-019-48060-0

Hodge A (2004) The plastic plant: root responses to heterogeneous supplies of nutrients. New Phytol 162:9-24. https://doi. org/10.1111/j.1469-8137.2004.01015.x

Hu B, Chu C (2019) Nitrogen-phosphorus interplay: old story with molecular tale. New Phytol. https://doi.org/10.1111 /nph.16102

Jackson RB, Canadell J, Ehleringer JR et al (1996) A global analysis of root distributions for terrestrial biomes. Oecologia 108:389411. https://doi.org/10.1007/BF00333714

Jia X, Liu P, Lynch JP (2018) Greater lateral root branching density in maize improves phosphorus acquisition from low phosphorus soil. J Exp Botany 69:4961-4970. https://doi. org/10.1093/jxb/ery 252

Kembel SW, Cahill JF (2005) Plant phenotypic plasticity belowground: a phylogentic perpsective on root foraging trade-offs. Am Nat 166:216-230

Kembel SW, De Kroon H, Cahill JF, Mommer L (2008) Improving the scale and precision of hypotheses to explain root foraging ability. Ann Bot 101:1295-1301. https://doi. org/10.1093/aob/mcn044

Klimeš L, Klimešová J (1994) Biomass allocation in a clonal vine: effects of intraspecific competition and nutrient availability. Folia Geobot 29:237-244. https://doi.org/10.1007/BF02803798

Koevoets IT, Venema JH, Elzenga JTM, Testerink C (2016) Roots withstanding their environment: exploiting root system architecture responses to abiotic stress to improve crop tolerance. Front Plant Sci 7:1-19. https://doi.org/10.3389/fpls.2016.01335

Kong D, Ma C, Zhang Q et al (2014) Leading dimensions in absorptive root trait variation across 96 subtropical forest species. New Phytol 203:863-872. https://doi.org/10.1111 /nph.12842

Kumar A, Shahbaz M, Koirala M et al (2019) Root trait plasticity and plant nutrient acquisition in phosphorus limited soil. J Plant Nutr Soil Sci. https://doi.org/10.1002/jpln.201900322

Lambers H, Shane MW, Cramer MD et al (2006) Root structure and functioning for efficient acquisition of phosphorus: matching morphological and physiological traits. Ann Bot 98:693-713. https://doi.org/10.1093/aob/mcl114

Lenth RV (2016) Least-Squares Means: The R Package lsmeans. Journal of Statistical Software 69:1-33

Luke McCormack M, Adams TS, Smithwick EAH, Eissenstat DM (2012) Predicting fine root lifespan from plant functional traits in temperate trees. New Phytol 195:823-831. https://doi.org/10.1111/j.1469-8137.2012.04198.x

Lynch JP (2013) Steep, cheap and deep: an ideotype to optimize water and $\mathrm{N}$ acquisition by maize root systems. Ann Bot 112: 347-357. https://doi.org/10.1093/aob/mes293

Lynch JP (2011) Root phenes for enhanced soil exploration and phosphorus acquisition: tools for future crops. 156:10411049. https://doi.org/10.1104/pp.111.175414
Lynch JP, Brown KM (2001) Topsoil foraging - an architectural adaptation of plants to low phosphorus availability. Plant Soil 237:225-237. https://doi.org/10.1023/A:1013324727040

McNickle GG, Brown JS (2014) When Michaelis and Menten met Holling: towards a mechanistic theory of plant nutrient foraging behaviour. AoB Plants 6:1-14. https://doi.org/10.1093 /aobpla/plu066

Mcnickle GG, Deyholos MK, Jr JFC (2016) Nutrient foraging behaviour of four co-occurring perennial grassland plant species alone does not predict behaviour with neighbours. 420-430. https://doi.org/10.1111/1365-2435.12508

Mommer L, Van Ruijven J, De Caluwe H et al (2010) Unveiling below-ground species abundance in a biodiversity experiment: a test of vertical niche differentiation among grassland species. J Ecol 98:1117-1127. https://doi.org/10.1111 j.1365-2745.2010.01702.x

Oram NJ, Ravenek JM, Barry KE et al (2018) Below-ground complementarity effects in a grassland biodiversity experiment are related to deep-rooting species. J Ecol 106:265-277. https://doi.org/10.1111/1365-2745.12877

Poorter H, Niklas KJ, Reich PB et al (2012) Biomass allocation to leaves, stems and roots: meta-analyses of interspecific variation and environmental control. New Phytol 193:30-50. https://doi.org/10.1111/j.1469-8137.2011.03952.x

Postma JA, Lynch JP (2012) Complementarity in root architecture for nutrient uptake in ancient maize/bean and maize/bean/ squash polycultures. Ann Bot 110:521-534. https://doi. org/10.1093/aob/mcs082

Postma JA, Lynch JP (2011) Root cortical aerenchyma enhances the growth of maize on soils with suboptimal availability of nitrogen, phosphorus, and potassium. Plant Physiol 156: 1190-1201. https://doi.org/10.1104/pp.111.175489

R Core Team (2018) R: A language and environment for statistical com- puting. Vienna, Austria: R Foundation for Statistical Computing. Retrieved from https:/www.r-project.org/

Reiss ER, Drinkwater LE (2018) Cultivar mixtures: a metaanalysis of the effect of intraspecific diversity on crop yield: a. Ecol Appl 28:62-77. https://doi.org/10.1002/eap.1629

Saengwilai P, Tian X, Lynch JP (2014) Low crown root number enhances nitrogen acquisition from low-nitrogen soils in maize 1 [ W ] [ OPEN ]. 166:581-589. https://doi. org/10.1104/pp.113.232603

Sánchez-Calderón L, López-Bucio J, Chacón-López A, CruzRamírez A, Nieto-Jacobo F, Dubrovsky JG, HerreraEstrella L (2005) Phosphate starvation induces a determinate developmental program in the roots of Arabidopsis thaliana. Plant Cell Physiol 46:174-184. https://doi.org/10.1093 /pcp/pci011

Schnepf A, Black CK, Couvreur V, et al (2019) Call for participation: collaborative benchmarking of functional-structural root architecture models. The case of root water uptake bioRxiv 808972. https://doi.org/10.1101/808972

Soleymani A, Shahrajabian MH, Naranjani L (2011) Determination of the suitable planting date and plant density for different cultivars of barley (Hordeum vulgare L.) in Fars. African J Plant Sci 5:284-286

Stibbe C, Märländer B (2002) Field emergence dynamics significance to intraspecific competition and growth efficiency in sugar beet (Beta vulgaris L.). Eur J Agron 17:161-171. https:/doi.org/10.1016/S1161-0301(02)00005-9 
Sun J, Ye M, Peng S, Li Y (2016) Nitrogen can improve the rapid response of photosynthesis to changing irradiance in rice (Oryza sativa L.) plants. Sci Rep 6:1-10. https://doi. org/10.1038/srep31305

Thuynsma R, Kleinert A, Kossmann J et al (2016) The effects of limiting phosphate on photosynthesis and growth of Lotus japonicus. South African J Bot 104:244-248. https://doi. org/10.1016/j.sajb.2016.03.001

Tilman D (1990) Constraints and tradeoffs: toward a predictive theory of competition and succession. Oikos 58:3. https://doi. org/10.2307/3565355

Van Wijk MT, Williams M, Gough L et al (2003) Luxury consumption of soil nutrients: a possible competitive strategy in above-ground and below-ground biomass allocation and root morphology for slow-growing arctic vegetation? J Ecol 91: 664-676. https://doi.org/10.1046/j.1365-2745.2003.00788.x

Vance CP, Uhde-Stone C, Allan DL (2003) Phosphorus acquisition and use: critical adaptations by plants for securing a nonrenewable resource. New Phytol 157:423-447. https://doi.org/10.1046/j.1469-8137.2003.00695.x

Venterink HO, Güsewell S (2010) Competitive interactions between two meadow grasses under nitrogen and phosphorus limitation. Funct Ecol 24:877-886. https://doi.org/10.1111 j.1365-2435.2010.01692.x

Wahl S, Ryser P, Edwards PJ (2001) Phenotypic plasticity of grass root anatomy in response to light intensity and nutrient supply. 1071-1078. https://doi.org/10.1006/anbo.2001.1551

Wang Y-L, Almvik M, Clarke N et al (2015) Contrasting responses of root morphology and root-exuded organic acids to low phosphorus availability in three important food crops with divergent root traits. AoB plants 7:plv097. https://doi. org/10.1093/aobpla/plv097

Warton DI, Duursma RA, Falster DS, Taskinen S (2012) smatr 3an $\mathrm{R}$ package for estimation and inference about allometric lines. Methods Ecol Evol 3:257-259. https://doi.org/10.1111 j.2041-210X.2011.00153.x

Weidlich EWA, Temperton VM, Faget M (2018) Neighbourhood stories: role of neighbour identity, spatial location and order of arrival in legume and non-legume initial interactions. Plant Soil 424:171-182. https://doi.org/10.1007/s11104-0173398-3

Weiner J, Thomas SC (1986) Size variability and competition in plant monocultures. Oikos 47:211-222

Wickham H (2016) ggplot2: Elegant Graphics for Data Analysis. Springer-Verlag, New York

Williamson LC, Ribrioux SPCP, Fitter AH, Ottoline Leyser HM (2001) Phosphate availability regulates root system architecture in Arabidopsis. Plant Physiol 126:875-882. https://doi. org/10.1104/pp.126.2.875

Wright A, Schnitzer SA, Reich PB (2014) Living close to your neighbors: the importance of both competition and facilitation in plant communities. Ecology 95:2213-2223. https://doi.org/10.1890/13-1855.1

Zhang D, Lyu Y, Li H et al (2019) Neighbouring plants modify maize-root foraging for phosphorus: coupling nutrients and neighbours for improved nutrient-use efficiency. New Phytol. https://doi.org/10.1111/nph.16206

Zhou W, Cheng X, Wu R, Han H, Kang F, Zhu J, Tian P (2018) Effect of intraspecific competition on biomass partitioning of Larix principis-rupprechtii. J Plant Interact 13:1-8. https://doi.org/10.1080/17429145.2017.1406999

Zuur AF, Ieno EN, Elphick CS (2010) A protocol for data exploration to avoid common statistical problems: data exploration. Methods Ecol Evol 1:3-14

Publisher's note Springer Nature remains neutral with regard to jurisdictional claims in published maps and institutional affiliations. 